\title{
176
}

Rupantaran : A Multidisciplinary Journal

Vol. IV : pp 176-188, October, 2020

ISSN : 2091-0061

https://doi.org/10.3126/rupantaran.v4i1.34215

Research Management Cell (RMC)

Dhankuta Multiple Campus, Dhankuta

Tribhuvan University, Nepal

\section{Effect of COVID-19 on Rural Economy at Eastern Terai of Nepal}

\author{
Tirtha Raj Timsina ${ }^{1}$ \\ Email: tirtha.timsina2@gmail.com
}

\section{Abstract}

This article aims to find out the effect of COVID-19 pandemic in rural agricultural economy. It is descriptive research so that the findings has tried to objectively described based on field survey the on the effects of pandemic at Pathari Shanishchare Municipality of Morang district situated in eastern Terai of Nepal. Rural economy of Nepal is primarily constituted by the dominance of agriculture and allied sectors which occupies two third of the domestic subsistence from the long year back. The world currently has passing through the panic effect of COVID-19 pandemic and none of the sectors has left behind from its effect. Evidence reveals that various sectors of Nepalese economy intensely influenced whereas the weaker segments of the society are hardest hit by pandemic. Despite the existence of effect in rural and agriculture sector in particular that has never anticipated, ultimately we are compelled to cope with such type of pandemic if existed anytime ahead. Therefore this study is one of the representative studies of the effect of pandemic through which rural people in general and the agricultural sectors in particular would be able to adapt the appropriate action plan in future. The study shows that the physical effect of this pandemic is comparatively lower but psychologically greater in nature. So the agriculture would be the better option to utilize surplus time and resources so that rural community as well as entire nation could cope with.

Key Words: aggravated, agriculture, anticipated, hardest hit, pandemic, rural economy

\section{Introduction}

The population composition of the world has been changing and gradually shifting from rural to urban settlement because of various factors associated with the

1. Mr. Timsina is a Lecturere of Rural Development at Bhaktapur Multiple Campus, Tribhuvan University. 
advent of modern technology and development facilities in these areas. Most of the countries in the world are shifting their production mechanism and pay high priority to the industrial production that compelled to concentrate rural people to the urban areas. That might be the principal reason behind the decreasing attraction in rural areas in general and agriculture and allied sectors in particular. The poor performance of agriculture in the LDCs is related to the many internal and external difficulties that, these countries face as they seek to develop this sector and achieve their objectives of improving food security and increasing export earnings. Their internal difficulties include low productivity, rigid production and trade structures, a limited skills base, short life expectancy and low educational qualifications, poor infrastructure, and inadequate institutional and policy frameworks (FAO, 2002).

Since poverty and vulnerability often characterize the living conditions of rural populations, social protection can be a highly relevant policy tool. Investments in social protection can support rural populations by increasing their access to health care and maternity leave, ensuring they receive adequate dietary intakes, allowing them to enjoy at least a minimum level of income security, ensuring they acquire quality education, and promoting and facilitating their engagement in decent and productive employment. In doing so, investments in social protection have contributed to reducing poverty and vulnerability, to promoting decent and productive employment for all, and to fostering inclusive growth (ILO, 2019). Rural areas, particularly in the developing world, are much less prepared to deal with the direct and indirect impact of the crisis. In most countries, and almost all lower income countries, rural inhabitants have much less access to adequate sanitation, health services, education, broadband internet, social protection or public infrastructure, such as electricity or access to roads (World Bank, 2020).

FAO (2017) stressed that the decline in the share of agriculture in total production and employment is taking place at different speeds and poses different challenges across regions. Although agricultural investments and technological innovations are boosting productivity, growth of yields has slowed to rates that are too low for comfort. Food losses and waste claim a significant proportion of agricultural output, and reducing them would lessen the need for production increases. However, the needed acceleration in productivity growth is hampered by the degradation of natural resources, the loss of biodiversity, and the spread of trans-boundary pests and diseases of plants and animals, some of which are becoming resistant to antimicrobials.

Nepal is one of the least developed countries with about 29 million population having 1.35 percent annual growth rate (UNFPANepal, 2017). Population composition in rural areas are quite more different from the national figure where growth rate is only 0.98 percent and even negative in some 27 districts from hill and mountain 
(CBS, 2014). However the Nepal is exploiting population dividend because according to Census 2011, working age population is more than 57 percent which would be most favorable demographic variable to meet Sustainable Development Goals (SDGs) during 2030. By nature, Nepalese economy is divided in to two types; they are Rural and Urban. Rural economy is characterized by the traditional, subsistence based, natural, human oriented more or less homogeneous pattern of production and distribution. In contrary urban economy, nowadays are moving to highly commercialized, modern, diversified and technically advanced economy with easy excess of real estate and financial intermediaries/institutions. Because of the less dependence to outsiders and modern technological advancements, Nepalese rural areas are comparatively normal and less effected by external interferences. Nevertheless it doesn't mean that they are out of reach from these current affairs because the mobility of the rural people in the name of either foreign migration or temporary settlement of outside their home makes it possible.

The world now is passing through the severely panic effect of COVID-19 pandemic which was firstly existed in 2019 December at Wuhan of China and had spread very rapidly all over the world. Since Nepal has infected lately, effect of COVID-19 has still increasing until the second week of November, 2020 and because of the lack of determined nature and unavailability of medicine to cure, nobody knows how long will it be continue? Even if the mortality rate of this country is low but Nepal is in a fragile situation due to the lack of sufficient health services and equipment that are essential for critical patients. By nature this virus has unlimited transmission from person to person, there is greater risk of rapid rate of out brakes at urban areas with compact settlement. But the evidence shows that, there are equal chances of transmission in rural areas as well despite its scattered nature. UN (2020), pointed out that the government of Nepal had announced the nationwide lockdown from $25^{\text {th }}$ of March to $21^{\text {th }}$ of July and partial lockdown, close-ups and other forms of travel restriction are still taking place, the entire economy including the industries and trade has totally disrupted which formally or informally affect the rural economies including agriculture as well as Small and Medium Enterprises (SME). Either they suffered from the lack of transporting inputs and raw materials that are essential for production or due to the demand deficiency, transport deficiency or due to some other causes. Even some of the agro-producers were compelled force selling or destroy their products during that time. Meanwhile the entire country has seriously suffered from acute rainfall, where the poorest and marginalized segment has hardest hit by the disaster. Due to which the effect of pandemic further aggravates the entire rural economy. Nepal's economy faced headwinds in the first half of Fiscal Yar (FY) 2020. Following three consecutive years of substantial economic expansion, with growth averaging 7.3 percent per year, Nepal's economy experienced headwinds in the 
agriculture, manufacturing, and the service sectors in the first half of FY 2020. The agriculture sector was impacted by a delayed monsoon coupled with an outbreak of armyworms, leading to a 1.7 percent (year-on-year) decline in paddy production (WB, 2020).

FAO (2020-b) specified that countries with existing humanitarian crises are particularly exposed to the effects of the pandemic, in terms of both direct and indirect impacts on people's health, and disruption of livelihoods, food supply chains and access to food, basic services as well as humanitarian assistance. The COVID-19 pandemic is increasingly affecting food systems through impacts on food supply and demand, decreases in purchasing power, the capacity to produce and distribute food, and the intensification of care tasks, all of which will have differentiated impacts and will more strongly affect the most vulnerable populations.

The World Bank (2020) outlined that pandemic risk is the expected value of the impact of widespread infectious disease in humans on human health, economies, and communities. Pandemics are epidemics (occurrence of disease above an expected norm) that affect at least several countries on more than one continent. A salient characteristic of this risk is that it combines a low probability of occurring with high, potentially catastrophic, global impact. These risks are substantial. A single severe flu pandemic could cost $\$ 3$ trillion. It's hard to imagine a more severe threat to ending absolute poverty or to boosting shared prosperity in developing countries.

ASEAN (2020) in its periodic report on pandemic stated that, key sectors have been affected, particularly travel and tourism, and retail and other services sectors; business operations hence supply chains disrupted; employment and livelihood put at risk; while consumer confidence has declined. The COVID-19 outbreak has diminished prospects of an economic recovery from a broad global slowdown last year. The current COVID-19 pandemic has led to over a million of confirmed cases and tens of thousands of fatalities worldwide. In addition to the disease's mortality and public health effects, it may lead to significant and lasting economic implications, including productivity losses, supply chain disruptions, labor dislocation, and potential financial pressure on businesses and households.

ADB (2020) published a report named "ADB brief" in June 2020 regarding COVID-19 and stated that, the pandemic has increased food security risks in Asia and the Pacific as strict quarantine measures and export bans on basic food items have affected all stages of food supply chains. To get rid of the massive effect of pandemic ADB suggested at least following two measure. Firstly, swift and comprehensive policy interventions should focus on protecting consumers and public health; securing supply chains for producers; and promoting fair labor, trade, sound macroeconomic policies, and regional cooperation. Secondly, post-COVID-19 agriculture sector reforms 
should support a transition from a labor-intensive supply chain to a more resilient and efficient agriculture system including smart agriculture and mechanization. World Farmer's Organizationc (WFO), keeping its slogan as "Farmers Never Give Up" stated that the pandemic outbreak of corona virus has an impact on the entire food supply chain, confirming in the most terrible way that we are all part of a food system that is interconnected and fragile and that solutions must be developed together. Farming has been recognized almost worldwide as an essential activity and farmers were asked to keep on working, even harder, to cope up with this new challenge. Nevertheless, each component of the food supply chain has an impact on farming activities, so each bottle neck occurring somewhere on the food supply chain, is having an impact on farmers. Countries lock-down and borders' closures are strongly impacting farmers' access to input like seeds, fertilizers and agrochemicals.

The disruption in global job market due to COVID-19 pandemic, thousands of Nepalese workers all over the world have been cut off from their jobs and suddenly returned or willing to back home or not been able to go back to their respective countries for work due to travel restriction. Due to which the direct pressure goes up to the rural economy. There are two conflicting views regarding the growing pressure of workforces in rural economy. Existence of unanticipated additional work force might have two types of effect. Some argued that they negatively effect in production and distribution in rural economy due to the excessive pressure. But some argued that it has positive impact in the entire economy, because the workforces could innovatively utilize their skill and knowhow what they have learnt in broad for barren and surplus land in one hand and start new small and cottage enterprises for livelihood on the other which makes additional sustainable contribution to the rural economies. So the present study aims to find out the actual impact of COVID-19 pandemic in rural economy especially in the Pathari Shanishchare Municipality of the Morang district located in the province one of Nepal.

\section{Materials and Methods}

\section{Study Area}

Pathari Shanishchare is one of the youngest municipalities formally declared by the government of Nepal on May, 2014 by joining three different existing VDCs namely; Pathari, Shanishchare and Hasandaha located at the eastern part of Morang district. It is surrounded by Letang, Urlabari, Ratuwamai, Sunwarshi Municipality and Kanepokhari Gaunpalika. Total population of this municipality according to census 2011, is 61,132 where 27,756 are male and 33,376 are female in 10 different wards. It is connected with east-west highway at Pathari bazaar. Having plenty of natural resources, this municipality is considered as one of the rich site in agriculture 
production. Along with the varieties of small and medium scale enterprises it has some innovation in the traditional agricultural system with easy access of different means of transportation. Despite the abundance agricultural and allied opportunities, there are a lot of families with migrant workers who are working within and outside the country (www.patharishanishcharemun.gov.np).

The natures of the data were qualitative as well as quantitative and derived from both primary and secondary source. Secondary data were collected from the records of Municipality, office of respective wards and other concerned institutions including with the various electronic sources. Primary data were collected from the field observation and key informants interview with semi-structured questionnaire and checklist. Purposive sampling design has been used for the comfort of the research. Two wards namely 6 and 7 of Pathari Shanishchare municipality were selected where agriculture as well as Small and Medium Enterprises (SME) are highly concentrated. Only 30 key informants were taken purposively representing 15 from each ward to collect the primary information. Only simple statistical tools like percentage and average has used for the analysis. The descriptive method has used to interpret the collected data and information.

\section{Results and Discussion}

The production and productivity of agriculture sector is remained backward in developing countries from Asia, Africa and Latin America. It is not merely due to the low quality and insufficiency of land resources but it is due to the lack of use of improved technology, skill of the workers, quality of seeds and better institutional arrangement such as financial facilities, cooperatives, warehouses, market and many others. Various studies of development reveal the fact that the achievement in the agricultural advancement in Japan and Mexico is not because of the quality land but due to their rapid mechanization, modernization and commercialization in traditional agricultural system. If not so, it has never heard that Japan and South Korea were said to be as same as Nepal, a developing Country before forty to fifty years. But let us compare where they are, and what is our position! Safeguarding the agriculture and supply chain would be the inevitable alternatives to escape from the panic effect of pandemic to human beings (Timalsina, 2019).

In one hand COVID-19 pandemic puts negative effects in the entire economy, but on the other hand evidence shows that it would have positive impact on Nepalese agriculture to some extents. Department of Agriculture of Nepal shows that until the end of the July, 2020 the paddy plantation is 95.6 percent which is about 15 percent higher than the same period of previous fiscal year that was 80.18 percent in 2019 (DoA-2020). This statistics reveals that even Nepalese workers in abroad as well as 
urban areas within the country have lost their job and compelled to go back to their home, it gives better performance at rural agrarian system by employing their labour in farmland which were left barren or not occupied properly. The attraction toward rural and agriculture sectors has been raised as a result of loosing job outside or realizing the fact that effect of transmission is comparatively weaker in the scattered and natural types of settlements.

\section{Existing effect of COVID-19 Pandemic in Rural Economy}

Because of the continuity in the growth of infection of COVID-19, the actual effect and the impact of the pandemic has not been determined yet. But however, some sorts of direct as well as indirect effect are existed in the life of common people. To find out the current effect of pandemic in the study area, some structured questions are asked in field survey to the respondents and their responses are shown in following sub-headings.

Parajuli (2020) identified that the agriculture sector has faced the utmost effect with the unavailability of agricultural inputs like seed, fertilizers, pesticides, machineries, agricultural tools and lack of adequate labour management. Similarly, due to disturbance in the transportation system, harvested food products in some rural areas are going to waste due to a shortage of proper market facilities.

World Bank (2020) in its press release quoted that "The economic consequences of the pandemic and impact on livelihoods across Nepal is expected to be the most acute for informal workers or those without social security or assistance, who are more at risk of falling into extreme poverty." It is further added that informal businesses make up around 50 percent of enterprises in Nepal and are the main source of income for most of the labor force. Within this group, urban informal sector workers and selfemployed households in urban areas are more vulnerable than rural households who can fall back on subsistence farming. Most informal firms operate with limited savings, and owners may face the difficult choice of staying home and facing starvation during the lockdown or running their business and risking infection.

Deuja (2020) mentioned in his blog that COVID-19 has opened the nation's eyes to the importance of small-scale rural producers for providing the population with fresh and nutritious food. It has highlighted the need for individuals, communities, organisations and government bodies to make traditional agriculture and family farming practices more sustainable and resilient in the face of future crises.

\section{Income and Occupational Status of Sampled Household}

To understand the basic income source and the occupational status of the household, researcher has raised the question to the respondent and they argued that, 
out of 30, 12 respondents are adopting only traditional agriculture as their occupation and main source of earning. Including with this, rest of others are taking agriculture as a complementary source for other occupation in rural areas.

Table 1: Occupational status and Income Sources of respondents

\begin{tabular}{clcc}
\hline S.N. & \multicolumn{1}{c}{ Sources of Income } & No. of Respondents & Percentage \\
\hline 1 & Traditional Agriculture & 12 & 40.00 \\
2 & Agriculture and Retail & 7 & 23.33 \\
& Shop(Kirana) & 5 & 16.66 \\
3 & Agro Business and Shop & 6 & 20.00 \\
\hline & Commercial Farming & $\mathbf{3 0}$ & $\mathbf{1 0 0}$ \\
\cline { 2 - 4 } & Total & & \\
\cline { 2 - 4 }
\end{tabular}

Source: Field Survey, 2020

Above table depicts that in rural areas of terai region, traditional agriculture is dominant occupation despite the access of varieties of technological and institutional support and there is still the greater potential in agricultural modernization.

\section{Sufficiency of Agricultural Production}

As agriculture is prime occupation of rural Nepal, Nepalese agriculture is still nature based and subsistence oriented. But however agriculture in terai region are either accessed with irrigation cannel of supply from underground through pump set. Therefore the farming household used to have access agro-production by which they maintain their other groceries. Out of 30 sampled household, only 10 percent doesn't have sufficient production and 20 percent produce only for own use. Rest of other are use to sell their surplus product.

Table 2: Product Self sufficiency from Agriculture

\begin{tabular}{clcc}
\hline S.N. & \multicolumn{1}{c}{ Production Status } & No. of Respondents & Percentage \\
\hline 1 & Sufficient only for Own Use & 6 & 20.00 \\
2 & Available for Selling in Smell scale & 9 & 30.00 \\
3 & Used to supply for Wholesaler & 12 & 40.00 \\
& Not Sufficient & 3 & 10.00 \\
\cline { 2 - 4 } & \multicolumn{1}{c}{ Total } & $\mathbf{3 0}$ & $\mathbf{1 0 0 . 0 0}$ \\
\cline { 2 - 4 }
\end{tabular}

Source: Field Survey, 2020

Above table shows that there is good agriculture production in eastern terai and the additional supply of manpower and technological can make the agricultural growth. 


\section{Effect of COVID-19 pandemic in rural occupation}

People in rural areas are primarily depending upon agriculture even if they used to have some other supporting occupation like, animal husbandry, poultry farming, fish pond, small scale enterprises. Some of the respondents argued that they couldn't identify the significant effect of pandemic, but however most of them felt some effect from it. But rather it is quite informal in nature. Some 20 percent argued that the current effect is greater 'reaction rather than reality' whereas 50 percent felt the psycho-social effect in their family.

Table 3: Effect of COVID-19 felt in everyday occupation

\begin{tabular}{clcc}
\hline S.N. & \multicolumn{1}{c}{ Responses } & No. of Respondents & Percentage \\
\hline 1 & Physically Effected in Occupation & 6 & 20.00 \\
2 & $\begin{array}{l}\text { Psycho-social Effect on Family } \\
\text { Member }\end{array}$ & 15 & 50.00 \\
3 & Reaction rather than Reality & 6 & 20.00 \\
4 & Not Identified Significant Effect & 3 & 10.00 \\
\hline & $\quad$ Total & $\mathbf{3 0}$ & $\mathbf{1 0 0 . 0 0}$ \\
\hline
\end{tabular}

Source: Field Survey, 2020

Above table signifies that people in the rural areas also affected by the pandemic in everyday life although it is dominantly informal in nature.

\section{Potential Measures to Curbs the Effect of COVID-19 Pandemic}

UNO (2020) from the Nepal chapter stated that the COVID crisis affecting the world today requires a level of response that goes beyond the capacity of any country. As the UN Secretary-General said; "More than ever before, we need solidarity, hope and the political will and cooperation to see this crisis through together". The Government of Nepal is putting in place a series of measures to address the situation, but more needs to be done, and the international solidarity is required to ensure that the country is fully prepared to face the pandemic and address its impact in all sectors.

FAO (2020-a) stated that as countries combat the COVID-19 pandemic, they must also make every effort to keep the gears of their food supply chains moving. First, health is the top priority. Countries must ramp-up testing as much as possible and put isolation measures in place in order to slow the spread. Second, countries should meet the needs of the most vulnerable people, as the measures to contain the pandemic cripple the economy. Third, countries must keep the food supply flowing by prioritizing the health of the workers in the sector and their outputs.

In this regard the actual response the people in the research area delivered some different strategies to minimize the pandemic effect. Out of 30 sampled respondent, 
50 percent argued that best strategy is the continue everyday work by following health awareness which is one of the best adaptation strategies to cope with pandemic. Similarly some 20 percent argued that people can avoid the effect bu utilizing time in farming which is less infected and discourage gathering too.

Table 4: Pandemic effect minimization strategy in rural area

\begin{tabular}{clcc}
\hline S.N. & \multicolumn{1}{c}{ Responses } & No. of Respondents & Percentage \\
\hline 1 & By Utilizing time in Farming Activities & 6 & 20.00 \\
2 & Start Small Business in Rural Area & 3 & 10.00 \\
3 & $\begin{array}{l}\text { Continue Everyday Work Following } \\
\text { Health Awareness }\end{array}$ & 15 & 50.00 \\
4 & Avoid Gathering(Social Distancing) & 6 & 20.00 \\
\hline & $\quad$ Total & $\mathbf{3 0}$ & $\mathbf{1 0 0 . 0 0}$ \\
\hline
\end{tabular}

Source: Field Survey, 2020

Government action in the short term needs to ensure the flow of critical food systems and value chains important for national and local food security and nutrition, as well as for the livelihoods of the vulnerable rural poor, including indigenous peoples, migrant and informal workers, and small-scale producers and enterprises. Response should focus on ensuring the continued and secured capacity of smallholders for food production and supply, including through extension and advisory services, promoting innovations that are local, increasing resilience and creating opportunities.

\section{Opportunities created by the Unprecedented Circumstances:}

COVID-19 has opened the nation's eyes to the importance of small-scale rural producers for providing fresh and nutritious food. It has highlighted the need for individuals, communities, organizations and government bodies to make traditional agriculture and family farming practices to be more sustainable and resilient in the face of future crises. Many are engaged in subsistence farming but there are opportunities for transforming agriculture activities to provide better returns and maintain equitable trading relations between rural and urban. The cooperative trading model, for example, could provide more direct producer-consumer relations that enable farmers to secure better prices and more favorable influence over the value chain. Establishing models for equitable market linkages for small-scale producers could help the country become more self-sufficient, rather than depending on cheaper imports from India that depress prices. There is the opportunity for local government to fix minimum prices of their products, to stop black marketing, and for this to continue post-COVID. This will help secure producer's rights to fix the price of their produce in relation to costs of production so that they get a fair deal. 
The actual perceptions of common people regarding the opportunities that are supposed to create now and after COVID pandemic are also collected during the field survey. Out of total selected respondent some 40 percent argued that pandemic ultimately increased the attraction of youth in agriculture in the sense that it has relatively smaller negative consequences by such disaster in future. Similarly they argued that COVID-19 provide sufficient manpower of agricultural activities in rural areas and the better uses of manpower and other available resources is possible.

Table 5: Opportunities Created by COVID-19 in Society

\begin{tabular}{|c|c|c|c|}
\hline S.N. & Types of Opportunities & No. of Respondents & Percentage \\
\hline 1 & Manpower Sufficiency & 8 & 26.66 \\
\hline 2 & Increased Attraction in Agriculture & 12 & 40.00 \\
\hline 3 & $\begin{array}{l}\text { Opportunity to gather Family at } \\
\text { Rural area }\end{array}$ & 4 & 13.33 \\
\hline 4 & $\begin{array}{l}\text { Better Use of Manpower and Land } \\
\text { Resources }\end{array}$ & 6 & 20.00 \\
\hline & Total & 30 & 100.00 \\
\hline
\end{tabular}

Source: Field Survey, 2020

The above table revels that the pandemic not only have negative consequences into entire human communities but it equally brings some of the potential opportunities through which intensification and commercialization of agriculture become possible. Eventually, even after delayed, development of rural areas takes place with agricultural mobilization which is the ultimate goal of LDCs like Nepal.

\section{Conclusion}

COVID-19 is a global pandemic which has firstly identified in December 2019 in China and has been spread rapidly all over the world and formally influenced all the sectors in the economy everywhere. Since its community transmission in Nepal has realized mainly after July, it has manifold impact and hardest hit to those who are in fragile condition. Among the various, Nepalese agriculture being as prime source of rural livelihood, contributing the one third of national GDP and subsistence sources more than two third of families in the country even today. Initially it has predicted that because of the scattered pattern of settlement, there would be insignificant effect in rural areas, eventually nowhere is safe from it. By nature this pandemic is basically related with human beings, the effect has been realizing weaker in rural areas in general and agriculture sector in particular. Common people argued that, because of the consumption of fresh and hygienic domestic product and the physical exercise which never stop are the major causes to lower impact in rural areas. Definitely the 
unplanned 120 days nationwide lockdown and segmented travel as well as other forms of restriction definitely hamper in the supply chain of the agro products from input supply to the selling of the product. But however the effect could sharply minimize through adaptation of strategies favored by common people in rural areas. If the surplus workforce could utilize properly in agricultural activities, it will not only easy to cope with the pandemic but also able to produce greater edible commodities so that the employment and trade deficit could addressed.

\section{References}

ASEAN. (2020 July). Economic Impact of COVID-19 outbreak on ASEAN. ASEAN Policy Brief. https://www.asean.org/storage/2020/04/ASEAN-Policy-BriefApril-2020_FINAL.pdf

Central Bureau of Statistics [CBS]. (2014). Population Monograph of Nepal, VolumeIII(Economic Demography). Kathmandu.: Central Bureau of Statistics.

Department of Agriculture (DoA) (2020). Statistical update of Paddy Production in Nepal. Retrieved in July 20, 2020 from: http://www.doanepal.gov. np/noticedetail/37/2020/57716411.

Deuja, J. (2020, May 11). Curbing the impacts of COVID-19 on Nepal's small-scale farmers and seizing opportunities for food system reform. https:/www.iied.org/curbing-impacts-covid-19-nepals-small-scale-farmersseizing-opportunities-for-food-system-reform.

Jonas, O. B. (2014). Pandemci Risk. World Development Report 2014 (pp. 1-40). Washington DC: The World Bank.

Food and Agricultural Organization [FAO]. (2002). The Role of Agriculture in the Development of Least-Developed Countries and Their Integration into the World Economy. Retrieved in August 5, 2020 from: http://www.fao.org/3/ay3997e.pdf.

FAO. (2017). The future of food and agriculture - Trends and challenges. Rome. Retrieved in August 5, 2020 from: http://www.fao.org/3/a-i6583e.pdf.

FAO. (2020-a). COVID-19 and the risk to food supply chains: How to respond? Rome. https://doi.org/10.4060/ca8388en) or (http://www.fao. org/3/ca8388en/CA8388EN.pdf.

FAO. (2020-b). Anticipating the impacts of COVID-19 in humanitarian and food crisis contexts. Rome. https://doi.org/10.4060/ca8464en;or, Retrieved in August 8, 2020 from: http://www.fao.org/3/ca8464en/CA8464EN.pdf. 
FAO. (2020-c). COVID-19 and rural poverty: Supporting and protecting the rural poor in times of pandemic. Rome. https://doi.org/10.4060/ca8824en.

International Labour Organization [ILO]. (2019). Extending Social Protection to the Rural Economy: Decent Work in the Rural Economy Policy Guidance Notes; Retrieved from: https:/www.ilo.org/wcmsp5/groups/public/---ed_dialogue/--sector/documents/publication/wcms_437192.pdf.

Parajuli, M. (2020, July 8). Agriculture and food production of Nepal under COVID-19. https://ypard.net/2020-07-08/agriculture-and-food-production-nepal-undercovid-19.

Timalsina, T.R. (2019). Agricultural Transformation Around Koshi Hill Region: A Rural Development Perspective. Nuta Journal, 6 (1 \& 2) 2075, 95-105. Retrieved in August 8, 2020 from: https://www.nepjol.info/index.php/nutaj.

USAID. (2008). Agricultural Recovery Responses in Postpandemic Situations Arising from Major Animal and Plant Diseases. Retrieved in August 5, 2020 from: http://www.hsdl.org/231734.pdf.

United Nations[UN]. (2020). COVID-19 in Nepal: Preparedness and Response Plan(NPRP). Retrieved in July 20, 2020 from: https://www.who.int/docs/defaultsource/nepal-documents/novel-coronavirus/covid-19-nepal-preparedness-andresponse-plan-(nprp)-draft-april-9.pdf?sfvrsn=808a970a.

The World Bank[WB]. (2020 July). Nepal Development Update. Retrieved in August 8, 2020 from: www.worldbank.org/np.

WB. (2020, October 8). COVID-19 impact on Nepal's economy hits hardest informal sector. Press Release. https:/www.worldbank. org/en/news/press-release/2020/10/08/covid-19-impact-on-nepals-economyhits-hardest-informal-sector. 